\title{
THE ASPECTS OF ENVIRONMENTAL LAW ENFORCEMENT IN INDONESIA AND THE IMPLEMENTATION OF INTERNATIONAL AGREEMENTS IN THE ENVIRONMENTAL FIELD IN INDONESIA
}

\author{
Yonani Hasyim ${ }^{1}$, Serlika Aprita ${ }^{2}$
}

\begin{abstract}
Law enforcement is the process of enforcing or trying to implement legal norms as guides for traffic or legal relations in social and state life. In the environmental law enforcement system in Indonesia, there are three legal aspects described in the Environmental Protection and Management Act (UUPPLH), namely administrative law, civil law, and criminal law aspects. Where each aspect's law enforcement and law enforcement processes are distinct. The research method used was normative legal research. One component of environmental law enforcement is the use of civil law in environmental management. In the Environmental Protection and Management Act (UUPPLH) the process of enforcing environmental law through civil procedures is regulated in Chapter XIII Articles 84 to 93. In order to provide legal clarity in law enforcement, efforts are being made to solve environmental problems that emerge in Indonesia. Environmental law enforcement is an endeavor to ensure that regulations and requirements in general and specific legal provisions are followed and implemented through administrative, civil, and criminal supervision and enforcement. With the adoption of the first environmental rules, namely Law Number 4 of 1982 Concerning Basic Provisions for Environmental Management (UUKPPLH), government policy frameworks in implementing environmental law were actualized. Then, it was later replaced by Law Number 23 of 1997 concerning Environmental Management (UUPLH), which was subsequently replaced by Law Number 32 of 2009 concerning Environmental Protection and Management (UUPPLH) (Tude Trisnajaya, 2013: 2). The research method used in this study was normative juridical research, which means it was done with an eye on the laws, rules, and court decisions that were relevant to the topic.
\end{abstract}

Keywords: Law Enforcement, Environment, Legal Norms, Dispute Resolution.

\section{The Introduction}

Civil law can also be used to enforce environmental laws. Because of the lengthy legal process, this route is not popular in Indonesia. Because the losing parties are invariably unsatisfied, almost all civil cases end up before the highest court for cassation. People tend to deliberately procrastinate by always using legal remedies, even if they are not unreasonable, and then they usually go through the process of reconsideration (Andi Hamzah, 2005: 89). According to Mas Achmad Santosa, the plaintiff must prove the existence of pollution as well as the link between the pollution and the losses sustained to identify a person or legal organization is accountable for losses caused by

\begin{tabular}{lllll}
\hline 1 & Fakultas Hukum Universitas & Muhammadiyah & Palembang, & Email \\
& nanihasyim1967@gmail.com & & & \\
2 & Fakultas Hukum Universitas & Muhammadiyah & Palembang, & Email \\
& 5312lika@gmail.com
\end{tabular}


pollution or environmental devastation. Proving involves assuring the judge that the disputed concrete occurrences are true (Mas Ahmad Santosa, 2001: 234).

Environmental issues are becoming increasingly complex and serious. It is like a snowball sliding downhill, growing larger and larger. The issue is regional, national, international, and global, not only local or trans-local. The environmental impacts are not only related to one or two aspects, but also to the nature of the environment, which has multi-link interactions that influence one another in subsystems. If one element of the environment is affected by problems, it will have an impact on or have consequences on other aspects (N.H.T Siahaan, 2004:1-2). The government introduced Law No. 32 of 2009 on Environmental Protection and Management (UUPPLH) on October 3,2009 . This law is a normative and political outcome of the initiative of the House of Representatives of the Republic of Indonesia.

Scientific evidence is crucial in environmental prosecutions because it is required to establish a causal relationship (cause and effect) between unlawful conduct and their consequences. In general, it can be claimed that employing scientific evidence in environmental disputes is still fraught with difficulties. Because of the judge's weak comprehension of science, interpreting scientific findings as legal proof remains a challenge. Whereas, a judge's knowledge of science is essential in determining and applying scientific facts to the legal framework, allowing for suitable and accountable decisions (Komang Trie Krisnsari, 2013: 2).

In order to provide legal clarity in law enforcement, efforts are being made to solve environmental problems that emerge in Indonesia. Environmental law enforcement is an endeavor to ensure that regulations and requirements in general and specific legal provisions are followed and implemented through administrative, civil, and criminal supervision and enforcement. With the adoption of the first environmental rules, namely Law Number 4 of 1982 Concerning Basic Provisions for Environmental Management (UUKPPLH), government policy frameworks in implementing environmental law were actualized. Then, it was later replaced by Law Number 23 of 1997 concerning Environmental Management (UUPLH), which was subsequently replaced by Law Number 32 of 2009 concerning Environmental Protection and Management (UUPPLH) (Tude Trisnajaya, 2013: 2).

In environmental management, we are dealing with the law as a means of fulfilling interests. As a scientific discipline that currently developing, most of the legal material environment is one part of administrative law (administratiefrecht). Environmental law also contains aspects civil, criminal, tax, international and spatial planning law so it cannot be classified into classical law field (public and private). Thus, the substance of environmental law itself raises the field in the form of environmental law administrative, civil environmental law, environmental law penal law. Criminal law is seen as an ultimum remedium meaning criminal law should be seen as a last resort in improve human behavior.

In Indonesia, the environmental damage that has occurred has already occurred very worrying, even to the point of causing damage what happens in future generations, so that in the end future generations get 
environmental problems that occur as a result of environmental damage in the past. Thus then What must or needs to be emphasized is that the environment itself must be viewed and managed for sustainable living not solely for growth and equitable development.

Awareness of environmental sustainability itself in Indonesia still very lacking, so as to reduce environmental problems in the future even more difficult due to lack of awareness at this time, so in this case what needs to be improved in order to achieving environmental sustainability is awareness of the importance of preserve and protect the environment

\section{Research Methods}

According to Manasse Malo and Sri Trisnoningtias, the method in research refers to the entire process of thinking from identifying research problems to articulating them in a framework, as well as gathering data for empirical testing, explanations, and drawing conclusions. The research method used in this study was normative juridical research, which means it was done with an eye on the laws, rules, and court decisions that were relevant to the topic. A qualitative descriptive method was employed to analyze the data (Ishaq, 2017:47).

\section{Discussion and Results}

\section{Definition of Environment}

The environment is defined in Article 1 point 1 of the General Provisions of Law Number 32 of 2009 (UUPPLH) as the unity of space with all objects, forces, conditions, and living things, including humans and their behavior, that affect nature itself, the continuity of life, and the welfare of humans and other living beings. The environment is a state of being as well as the quantity of objects in the space where humans dwell that can have an impact on their lives. A good living environment is defined not only by the ability of humans to realize their desires to meet their fundamental requirements, but also by the ability of humans to play a role in maintaining the ecological balance (Suryono, 2013: 78).

The drafting of sanctions in the applicable laws and regulations contains the application of criminal law in combating environmental offences. Administrative sanctions, criminal sanctions, and civil sanctions are all governed by Law 32 of 2009 on Environmental Protection and Management. Environmental law provisions in Law Number 32 of 2009 provide legal norms relating to environmental protection and management rights, obligations, and authorities (Siti Sundari Rangkuti, 2000:2). Criminal sanctions are one sort of sanction intended at enforcing or ensuring compliance with the law's requirements on environmental management. From Article 97 to Article 120 of Law No. 32 of 2009, criminal provisions are regulated. The formulation of environmental offenses is qualified in material and formal offenses as a result of these provisions. Material offenses are defined in Articles 98, 99, and 112, whereas formal offenses are defined in Articles 100-111, 113-115. 


\section{Scientific Evidence}

Scientific evidence is the accumulation of evidence in the form of examples that are regarded necessary to demand expert explanations in specific domains (Muhammad Akib, 2014: 23). Scientific data is frequently related with environmental challenges in Indonesian developments. Only the Chairman of the Supreme Court's judgment 36/KMA/SK/II/2013 about the Enforcement of Guidelines for Handling Environmental Cases expressly describes the arrangement regarding scientific evidence. The extension of evidence not regulated in Article 184 of the Criminal Procedure Code (KUHAP) is only explained in Law Number 32 of 2009 concerning Environmental Protection and Management (UUPPLH), but it does not clarify the nature and scope of scientific findings as evidence in court. Based on the Chairman of the Supreme Court's Judgment Number 36/KMA/SK/II/2013 concerning the Implementation of Guidelines for Handling Environmental Cases, various kinds of scientific evidence include the results of laboratory analysis, calculation of compensation due to pollution and or damage from experts. To be used as legal evidence, scientific evidence must be backed up by expert testimony at trial. The existence of scientific evidence and other technical evidence is frequently required for the proper handling of environmental claims in court. The purpose of using a considerable amount of scientific evidence in practically every environmental issue is to establish a causal (cause-and-effect) relationship between unlawful conduct and their consequences. While scientific evidence can help a case, it is sometimes excluded from the courtroom or court. Before this might be presented in a courtroom as legal evidence, it must often go through a series of processes (Sodikin, 2007: 94). Before a scientific theory may be offered as evidence in court, it must first establish itself in the scientific community and be widely acknowledged as true.

\section{Application of Scientific Evidence in Environmental Crimes}

The problem of proof is one of the challenges in enforcing environmental laws. This issue is related to the laboratory's role, as well as the complex technical nature of the problem, the range of disciplines involved, and the legal requirements for proof and expert witness. Scientific evidence is critical for environmental issues, particularly forest and land fires (Karhutla), because only scientific evidence can expose all field facts (Takdir Rahmadi, 2015: 3). Starting with the experts involved (qualified experts), the methods utilized, the tools employed, and the technological instruments used, only field facts and laboratory analysis results are used, with low and highresolution satellite data. Through the Chairman of the Supreme Court's Judgment Number 36/KMA/SK/II/2013 about the Enforcement of Guidelines for Handling Environmental Cases, the Supreme Court has compiled guidelines for handling environmental cases that include requirements on scientific and expert evidence (N.H.T. Siahaan, 2008:53-58). Scientific evidence can be used in environmental cases based on the decree. The procedure of proving scientific evidence in environmental cases is a challenge that plays a significant role in the trial process. Judges must be able to evaluate scientific evidence. There may be divergent viewpoints expressed by experts. The Chairman of the Supreme Court's Judgment Number 
36/KMA/SK/II/2013 concerning the Implementation of Guidelines for Handling Environmental Cases has accommodated scientific evidence if there are different expert statements, the judge can choose information based on the judge's belief by providing reasons for choosing the evidence presented by the judge, expert testimony, presenting other experts with the imposition of fees based on the agreement of the parties (Koesnadi Hardjo Soemantri, 2012: 8-9).

Law enforcement is a term that has diversity definition. Law enforcement is the process of making efforts to enforce or actual functioning of legal norms as behavioral guidelines in relationships-legal relations in the life of society and the state (Kartono Kartono, 2009:249). According to Satjipto Rahardjo, law enforcement is defined as a process to realize the wishes of the law, namely the thoughts of the legislature formulated and stipulated in legal regulations which later became reality (Satjipto Rahardjo, 1993: 15)

Environmental law enforcement is the last link in the regulatory cycle policy planning on the environment in the following order: 1). Law invitation, 2). Standard setting, 3). Granting permits, 4).Implementation, 5).Law enforcement. In environmental law enforcement, it is adopted in the law enforcement system in a broad sense which includes preventive law enforcement and repressive law enforcement (Yunus Wahid,2018:187)

Repressive environmental law enforcement is aimed at tackling destruction and or pollution of the environment by imposing or imposing sanctions (punishment) to environmental destroyers or polluters which can be in the form of criminal sanctions (imprisonment and fines), civil sanctions (compensation and/or certain actions), and/or administrative sanctions (government coercion, forced money, and revocation of permits). Whereas preventive environmental law enforcement is aimed at preventing the occurrence of actions or actions that can cause environmental damage or pollution Today, legal instruments aimed at enforcing environmental laws that are preventive in nature, these are AMDAL (Environmental Impact Analysis) and Licensing (Zairin Harahap, 2004:8).

In terms of settlement of environmental disputes, Article 84 paragraph (1) of Law No. 39 In 2009, it is divided into two parts, namely settlement through court (litigation) and settlement outside the court (nonlitigation, in the article says: "Environmental dispute resolution can be reached through the courts or outside court".

However, the provision in paragraph (3) provides further provisions regarding court proceedings which can only be done if the dispute resolution outside the chosen court is declared cannot find an agreement, either one of the parties or the litigants. So, in the event that the lawsuit to the court is not immediately carried out, but must be mediation efforts are carried out to find win-win solutions in environmental problems, especially for those who are harmed in this case.

The provisions for Settlement of environmental disputes outside the court are carried out to reach an agreement on: 1) the form and amount of compensation; 2) action recovery due to pollution and/or destruction; 3) certain measures to ensure no there will be recurrence of pollution and/or destruction and/or; 4) action to prevent the emergence of negative impacts on 
the environment. If efforts have been made to litigation but there is no agreement between the two parties, so for those who feel nosatisfied or feel disadvantaged, be it the government or the community can take the route litigation (administrative, civil and criminal).

\section{Obstacles in the Application of Scientific Evidence in Environmental Crimes}

The criminal justice system, as a means of preventing preventing and resolving crimes in the community, plays a significant role in overcoming environmental crimes. In order to find the material truth, the stages of proof are crucial in the criminal justice process in Indonesia. The agenda of the evidentiary hearing represents the events that transpired based on valid evidence during the evidential stage (M. Daud Silalahi, 2015:12-15). Article 96 of the Environmental Protection and Management (UUPPLH) regulates the admissibility of legitimate evidence such as witness statements, expert statements, letters, instructions, defendants' statements, and other evidence, including evidence regulated by legislation. The judge can see from the evidence offered to him during the proof stage, and he has the authority to make a decision based on the information and evidence. Environmental crimes are investigated in a method that is nearly identical to other types of crimes. The processes are also the same, with the exception of the sort of offence. For environmental crimes, experts must declare that the environment has been polluted, after which the investigation can be expanded into a full investigation. This is important because the National Police's authority to undertake investigations must be founded (legal standing). Environmental crimes are difficult to investigate because, in addition to collection, samples must be tested in a laboratory. Testing in a laboratory aims to see whether the content is excessive or not. As a result, in the form of a report or letter, or a Police Investigation Report by Investigators, it needs an expert to provide information on the content level. This is what is known as scientific evidence, which will be converted into legal evidence before the trial (legal evidence). Judges may also have difficulty in assessing the capacity of experts from domains other than law. Judges must determine whether or not an expert has specialized knowledge and expertise. Judges have complete power to determine who has unique expertise and experience in a specific area and can assist an expert. Nonetheless, the judge's correctness is a must when determining expert qualifications.

Since the issuance of UUPPLH 2009 which replaces Law no. 23 of 1997 (hereinafter referred to as UUPPLH 1997), the functions of as the main law attached to UUPPLH 2009. UUPPLH called bringing about a fundamental change in settings environmental management in Indonesia today. If you look closely Furthermore, there are some significant differences in arrangements between UUPPLH 1997 and UUPPLH 2009.

First, the 1997 UUPPLH formulated a criminal act as a actions/deeds that may result in pollution and/or damage to the environment (as regulated in Article 41), while the 2009 UUPPLH formulates a criminal act that is, as an action that can result in being exceeded ambient air quality standards, water quality standards, sea water quality standards, or standard criteria for environmental damage (as regulated in Article 98). Second, UUPPLH 1997 
formulates criminal penalties by: maximum penalty, while the 2009 UUPPLH formulates a criminal with a minimum and a maximum. Third, UUPPLH 2009 regulates about what things are not regulated in UUPPLH 1997, namely One of them is punishment for standard violations quality (as regulated in Article 100), expansion of equipment evidence, integration in criminal law enforcement, and regulation against corporate crime

The explanation of UUPPLH 2009 also explains the differences between Fundamental to UUPPLH 1997 is about strengthening contained in this Law, namely regarding the principles of environmental protection and management based on on good governance because every process in formulation and implementation of prevention instruments pollution and/or environmental damage as well as countermeasures and law enforcement are required to integrat aspects of transparency, participation, accountability, \& fairness (So Woong Kim, Kebijakan Hukum Pidana Dalam Upaya Penegakan Hukum Lingkungan Hidup, 2013:80-90).

Dependence on the application of criminal law is based on the state of administrative sanctions that have been imposed are not complied with, or the violation is committed more than once. The criminal threat not equal to or lighter than the maximum criminal limit regulated in the Criminal Code, and in particular Article 97 to Article 115 UUPPLH 2009, actually it is still possible/allowed to be criminal lighter. This can cause confusion in the process environmental criminal law enforcement, especially in decisions judge in an effort to deter the perpetrator.

Law enforcement regarding environmental management when This is still difficult to do because of the difficulty of proving and determine standard criteria for environmental damage (Sutrisno, 2011:444) Enforcement efforts environmental law through criminal law is what are the three main problems in this aspect of criminal law set forth in a law which more or less has role to carry out social engineering, which includes: formulation of a criminal act, criminal liability, and sanctions, both criminal and disciplinary. In accordance with the The purpose of criminal law is not only as a tool of order, but also Environmental law also contains the goal of reform society (social engineering). Law as a tool of social engineering has a very important role in environmental law (Wahyu Lukito, 2018:65)

In addition to UUPPLH, crimes against the environment Life is also regulated in the Criminal Code (KUHP), for example in Article 187, Article 188, Article 202, Article 203, Article 502, and Article 503 of the Criminal Code. Crime against environment is also contained in the legislation outside the Criminal Code and outside the UUPLH. For example in: Article 52 paragraph (1) UU no. 5 of 1960 concerning Basic Basic Regulations Agrarian Law/UUPA. Article 31 of Law no. 11 of 1967 About Mining. Article 11 of Law no. 1 of 1973 concerning the Foundation Indonesian Continent. Article 15 of Law no. 11 of 1974 About Irrigation. Article 16 paragraph (1) of Law no. 5 of 1983 concerning the Zone Indonesia's Exclusive Economic Zone (EEZ). Article 27 of Law no. 5 of 1984 concerning Industry. Article 24 of Law no. 9 of 1985 concerning Fisheries. Article 40 of Law no. 5 of 1990 concerning Natural Resources Conservation Life and its Ecosystem. Article 78 of Law no. 41 of 1999 About Forestry, and Article 94 paragraphs (1) and (2) jo. Article 95 paragraphs (1) and (2) of the Law No. 7 of 2004 concerning Water Resources. 
Environmental crimes or crimes are contained in various laws and regulations other than UUPLH and the Criminal Code. Therefore, the scrutiny of law enforcement, especially investigators, public prosecutors and judges are indispensable in find laws and regulations relating to environmental crime in various regulations that legislation. In other words, the rules which legislation to use, depends on what resources the environmental crime was committed. Environmental protection and management in essence is an effort to apply ecological principles in activities humans to and/or those with environmental dimensions (M. Yunus Wahid, 2011: 163-179)

In the future, the efforts that can be made in order to enforcement of criminal law in the environmental field are as follows: First, the need for reforming the pattern of punishment and criminal sanctions in the Environmental Management Law which has values legal certainty and the values of justice that are upheld by all party; and second, the need for reforming the pattern of punishment and sanctions criminal law in the Environmental Management Law which should be synchronous and consistent with the Criminal Code and the Draft Criminal Code in the future future.

\section{Conclusion}

The Law No. 32 of 2009 on Environmental Protection and Management (UUPPLH) merely explains the expansion of evidence not covered by Article 184 of the Criminal Procedure Code (KUHAP), but it leaves out the definition and extent of scientific evidence as evidence a court of law. Starting with the experts involved (qualified experts), the methods utilized, the tools employed, and the technological instruments used, only field facts and laboratory analysis results are used, with low and highresolution satellite data. Through the Chairman of the Supreme Court's Judgment Number 36/KMA/SK/II/2013 about the Enforcement of Guidelines for Handling Environmental Cases, the Supreme Court has compiled guidelines for handling environmental cases that include requirements on scientific and expert evidence. The method of proving scientific evidence in environmental cases is a challenge that plays a significant role in the trial process.

The Chairman of the Supreme Court's Judgment Number 36/KMA/SK/II/2013 concerning the Implementation of Guidelines for Handling Environmental Cases has accommodated scientific evidence if there are different expert statements, the judge can choose information based on the judge's belief by providing reasons for choosing the evidence presented by the judge, expert testimony, presenting other experts with the imposition of fees based on the agreement of the parties. Valid evidence consisting of witness statements, expert statements, letters, instructions, defendants' comments, and/or other evidence, including evidence regulated in legislation, is regulated in Article 96 of the Environmental Protection and Management (UUPPLH). 


\section{References}

Akib, Muhammad. (2014). Hukum Lingkungan Persfektif Global dan Nasional. Rajawali Pers.

Hamzah, Andi. (2005). Penegakan Hukum Lingkungan. Sinar Grafika.

Ishaq. (2017). Metode Penelitian Hukum. Alfabeta Bandung.

Koesnadi Hardjo Soemantri. (2012). Hukum Tata Lingkungan Edisi VIII. Gadjah Mada University Press.

Krisnsari, Komang Trie \& Mertha, I Ketut. (2013). Penerapan UndangUndang Nomor 32 Tahun 2009 Tentang Perlindungan Dan Pengelolaan Lingkungan Hidup Dalam Upaya Penegakan Hukum Lingkungan Di Indonesia. 1(3), 80-90.

Kartono. (2009). Penegakan Hukum Lingkungan Administratif Dalam Undang-Undang Perlindungan Dan Pengelolaan Lingkungan Hidup. Jurnal Dinamika Hukum, 9 (3), 285-295. http://dx.doi.org/10.20884/1.jdh.2009.9.3.236

Kim, So Woong. (2013). Kebijakan Hukum Pidana Dalam Upaya Penegakan Hukum Lingkungan Hidup. Jurnal Dinamika Hukum, 13 (3), 80-90. http://dx.doi.org/10.20884/1.jdh.2013.13.3.247

Lukito, Wahyu. (2018). Implementasi Pelestarian Lingkungan Hidup Dalam Bidang Penegakan Hukum Pidana Terhadap Kasus Illegal Logging (Studi Kasus Polres Rembang). Jurnal Hukum Khaira Ummah, 13(1), 153-160.

Rahmadi, Takdir. (2015). Hukum Lingkungan di Indonesia (Edisi Kedua). Rajawali Pers.

Rangkuti, Siti Sundari. (2000). Hukum Lingkungan dan Kebijaksanaan Lingkungan Nasional. Universitas Airlangga Press.

Santosa, Mas Ahmad. (2001). Good Governance Hukum Lingkungan. ICEL.

Silalahi, M. Daud \& Kristianto P.H. (2015). Hukum Lingkungan Dalam Perkembangannya Di Indonesia. Keni Media.

Siahaan, N.H.T. (2004). Hukum Lingkungan dan Ekologi Pembangunan. Erlangga.

Siahaan, N.H.T. (2008). Hukum Lingkungan, Pancuran Alam. Jakarta.

Sodikin. (2007). Politik Hukum Penegakan Hukum Lingkungan. Djambatan.

Suryono. (2013). Pencemaran Kesehatan Lingkungan, EGC, Qurratur $R$. Estu Tiar. Jakarta.

Sutrisno. (2011). Politik Hukum Perlindungan dan Pengelolaan Lingkungan Hidup. Jurnal Hukum, 3 (18), 444-464. https://doi.org/10.20885/iustum.vol18.iss3.art8

Trisnajaya, Tude \& Kasih, Desak Putu Dewi. (2013). Penerapan Penegakan Hukum Lingkungan Terkait Dengan Pencemaran Udara Di Kota Denpasar Setelah Keluarnya Peraturan Gubernur Bali Nomor 8 Tahun 2007 Serta Upaya Penanggulangannya. Kertha Semaya, 1 (9). https://doi.org/10.30975/.vol1.iss9.art8 
Wahid, M. Yunus. (2011). Prinsip Dan Karakter Hukum Lingkungan. Jurnal Ilmiah Hukum "Ishlah", 13 (2). 1-23.

Wahid, M Yunus. (2018). Pengantar Hukum Lingkungan. Kencana. 